\title{
Investigation of the effects of experimental cryptorchidism formed in prepubertal rats during the postpubertal and adult periods
}

\author{
Ozbag $\mathrm{D}^{1}$, Gumusalan $\mathrm{Y}^{1}$, Ozkaya $\mathrm{M}^{2}$, Ciralık $\mathrm{H}^{3}$, Tolun $\mathrm{FI}^{4}$, Yuzbasıglu $\mathrm{F}^{5}$, Bakan $\mathrm{V}^{6}$, \\ Arslan $\mathrm{S}^{7}$, Okumus $\mathrm{M}^{8}$ \\ Department of Anatomy, Faculty of Medicine, Kahramanmaras Sutcu Imam University, Kahramanmaras, Turkey. \\ davutozbag@hotmail.com
}

\begin{abstract}
Objective: Investigation of the effects of experimental cryptorchidism formed in prepubertal rats during the postpubertal and adult periods.

Material and methods: The abdominal cavities of 20 rats in the control group were just opened and closed without any further surgical procedure. The testicles of 20 rats in the experimental group were fixed to the anterolateral wall of the abdominal cavity under general anesthesia. At the 6th month, blood and testis tissue samples of rats were obtained and the rats were sacrificed and the experiment was terminated. Statistical analysis was done by SPSS 15.0 package software.

Results: The histopathological evaluation of testicular tissues of rats in the control group was in the normal limits. Of the experimental group, the testicular tissues had injury in nearly half of the rats, in which the testicles were fixed in the abdomen for three months that is the 1st subgroup. FSH levels were statistically significantly elevated in both experimental groups of rats $(p<0.01)$.

Discussion and conclusion: Cryptorchidism formed experimentally causes a partial damage in the testicular tissue of pubertal rats, however the damage increases gradually in the testicles of rats, in which the testicles were descended and left in the scrotum for another three months. The statistically elevated levels of FSH in both experimental groups of rats can be accounted for severe testicular damage. The timing in descending the undescended testicles to the scrotum is essential and should be performed before the puberty and as early as possible in avoiding the risk of infertility (Tab. 3, Fig. 5, Ref. 44). Full Text in PDF www.elis.sk.

Key words: testicle, infertility, cryptorchidism, rat.
\end{abstract}

Fertility is a vital issue for the maintenance of human being and other living creatures. Sustaining fertility is possible with the determination and treatment of the causes of infertility.

Cryptorchidism is a developmental insufficiency during the descent of the testicles from the abdominal cavity into the scrotal pouch. Undescended testis or cryptorchidism is one of the frequently encountered problems in boys.

${ }^{1}$ Department of Anatomy, Faculty of Medicine, Kahramanmaras Sutcu Imam
University, Kahramanmaras, Turkey, ${ }^{2}$ Department of Endocrinology, Facul-
ty of Medicine, Kahramanmaras Sutcu Imam University, Kahramanmaras,
Turkey, ${ }^{3}$ Department of Pathology, Faculty of Medicine, Kahramanmaras
Sutcu Imam University, Kahramanmaras, Turkey, ${ }^{4}$ Department of Bioche-
mistry, Faculty of Medicine, Kahramanmaras Sutcu Imam University, Kah-
ramanmaras, Turkey, ${ }^{5}$ Department of General Surgery, Faculty of Medi-
cine, Kahramanmaras Sutcu Imam University, Kahramanmaras, Turkey,
${ }^{6}$ Department of Pediatric Surgery, Faculty of Medicine, Kahramanmaras
Sutcu Imam University, Kahramanmaras, Turkey, ${ }^{7}$ Department of Nursing,
Higher School of Health, Kahramanmaras Sutcu Imam University, Kahra-
manmaras, Turkey, and ${ }^{8}$ Department of Emergency Medicine, Faculty of
Medicine, Kahramanmaras Sutcu Imam University, Kahramanmaras, Turkey

Address for correspondence: D. Ozbag, MD, Department of Anatomy, Faculty of Medicine, Kahramanmaras Sutcu Imam University, Kahramanmaras, 46050, Turkey.

Phone: +90.344.2237666/411, Fax: +90.344.2257534

Acknowledgement: Supporting Foundation; Scientific Research Projects Administration Unit of Kahramanmaras Sutcu Imam University, Project number; 2007/3-23.
It is encountered with a rate of 9-30\% in premature and $3-6 \%$ in term boys, as well as in $1 \%$ in the first age and remains the same in $0.7 \%$ until puberty. The most important risks of long term complications in undescended testis are infertility and development of malignancy. Malignant degeneration was reported as 5-40 fold higher than normal $(1,2)$.

Development of testis starts at the 6-7th weeks of intrauterine life and continues until adolescent period in humans. Hormonal secretion starts at the 8 th week in the fetal testis $(1,2)$.

Histopathological changes were observed in the testicles of boys with undescended testis as early as $1-2$ years of age. These were the decrease in the Leydig cell counts, degeneration in sertoli cells, decrease in germ cell counts and inadequate development of spermatocytes $(1,2)$. Fertility is affected much more in bilateral cases (3). Regular mechanism of testicular descent is a combination of complex hormonal and anatomical factors and the real process isn't known yet $(4,5)$.

It is well known that cryptorchidism affects male fertility through germ cell degeneration. However, being a real father is also affected from other factors such as fertility and age of the woman. Hormonal levels and semen quality have partial effects upon fertility potency $(6,7)$.

Descending of the testicles from abdomen into scrotal pouch in the late period does not lessen the risk of infertility, however it can stop the degeneration in the testis (8). 
Germ cells are absent and Leydig cells are hypoplasic in intraabdominal testes. The germ cell count is normal in cryptorcidic testes in the first year of life, but it decreases after the second year and results in infertility in adulthood.

While germ cell aplasia is seen at a rate of only $1 \%$ in normal children of $1-2$ years, it is encountered at $20 \%$ in 2 years, $40 \%$ in 6 years and $45 \%$ in 10-11 years of age in children with cryptorchidism. Absence of spermatogenesis is not congenital, but it is thought to develop secondary to germ cell degeneration $(9,10)$.

Cryptorchidism affects $3-4 \%$ of term male infants, and it is known that bilateral testicular descensus abnormalities may result in azospermia even though they have been corrected in early childhood (11).

It has been reported that a significant difference was not found in the "fertility index" between undescended testis and testis descended to the scrotum after intervention in patients of one year or under (12). But this difference was found rather significant in other groups of ages. Fertility was evaluated in a study in 91 patients with unilateral cryptorchidism who had orchiopexy in postpubertal period. Azospermia or oligospermia was determined in $83.5 \%$ of patients (13).

The problems during the descent of testis in the fetal life and the persistence of testis in the abdomen, especially in human, result in severe infertility. Serious problems may occur if the testicles are not descended from the abdominal cavity into the scrotal pouch directly after birth. Therefore, the experimental cryptorchidism formed in prepubertal rats and its effects during the postpubertal and adult periods were studied in this study. Other factors and the measures that can be introduced to prevent infertility were also evaluated.

We aimed to investigate the effects of experimental cryptorchidism formed in prepubertal rats on the development of testis and hormonal values in postpubertal and adult periods.

\section{Materials and methods}

Forty wistar albino male rats, twenty-one days old, were included in this study with the permission from Kahramanmaras Sutcu Imam University Medical Faculty Local Ethics Committee on Experimental Animal Research. Probable parents were breeded to obtain those twenty-one day old male rats and then only healthy juvenile male rats were selected following birth.

Rats were divided into the two groups as the Control and the Experimental group at the beginning of the experiment. Then they were anesthetized with a combination of ketamin HCL + xylazine HCL. Abdominal wall of the rats were dissected in the Experimental group after anesthesia. Testes of the rats were passed through the inguinal canal into the abdominal cavity and were fixed to the posterior surface of the anterolateral abdominal wall at the same level with the inferior border of the kidneys and then abdominal wall was closed. Anterior abdominal wall was only opened and closed in the Control group of rats (Tab. 1).

Rats in the Experimental group were divided into the two subgroups after three months. Blood and testis tissue samples were obtained from the first half (Group 2) under deep anesthesia and then they were sacrified. Testes those had been already fixed to the
Tab. 1. Experimental Design of Study.

\begin{tabular}{ll}
\hline Groups $(\mathrm{n}=40)$ & Procedures \\
$\begin{array}{l}\text { Group 1 } \\
\text { Control group) }(\mathrm{n}=10)\end{array}$ & $\begin{array}{l}\text { Abdominal cavity of rats was opened and } \\
\text { closed at the beginning of the experiment } \\
\text { and rats were sacrified after three months } \\
\text { from the begining. }\end{array}$ \\
\hline $\begin{array}{l}\text { Group 2 } \\
\text { Experimental group) }(\mathrm{n}=10)\end{array}$ & $\begin{array}{l}\text { Testes of the rats were ascended from the } \\
\text { scrotal pouch and fixed on the posterior } \\
\text { aspect of antero-lateral abdominal wall at } \\
\text { the beginning of the experiment and rats } \\
\text { were sacrified after three months from the } \\
\text { surgery. }\end{array}$ \\
\hline $\begin{array}{l}\text { Group 3 } \\
\text { (Control group) (n=10) }\end{array}$ & $\begin{array}{l}\text { Abdominal cavity of the rats was only } \\
\text { opened and closed at the beginning and } \\
\text { third month of the experiment and rats } \\
\text { were sacrified at the end of sixth month. }\end{array}$ \\
\hline Group 4 \\
(Experimental group) $(\mathrm{n}=10)$ & $\begin{array}{l}\text { Testes of the rats were ascended from the } \\
\text { scrotal pouch and fixed on the posterior } \\
\text { aspect of antero-lateral abdominal wall at } \\
\text { the beginning of the experiment and de- } \\
\text { scended again to the scrotal pouch at the } \\
\text { third month and the rats were sacrified at } \\
\text { the 6th month. }\end{array}$ \\
\hline
\end{tabular}

posterior surface of anterolateral abdomial wall were re-descended surgically through the inguinal canal into the scrotal pouch in the second half (Group 4). On the other hand, the Control group rats were also divided into two halves. Blood and testis tissue samples were obtained from the first half under deep anesthesia (Group 1) and then they were sacrified. The abdominal cavity was only opened and closed in the second half of the rats (Group 3) (Tab. 1).

Blood and testis tissue samples were obtained from the second halves of the Control and Experimental group rats (Group 3 and 4) under deep anesthesia and then they were sacrified after six months from the beginning of the experiment (Tab. 1).

Blood specimens were collected in $8 \mathrm{~mm}$ tubes with gel. Specimens were centrifugated at $4000 \mathrm{rpm}$ for 10 minutes after coagulation. The sera obtained were kept at $-20{ }^{\circ} \mathrm{C}$ until study time in eppendorf tubes.

Serum testosteron, LH, FSH, estradiol, TSH levels were studied with EIA (Enzyme immunoassay) method. Testosteron, estradiol (Cayman Chemical Company, USA) and rat TSH ELISA KIT (Shibayagi Co. Ltd. Japan) and LH- RH EIA KIT (Phoenix Pharmaceutical Inc. USA) and rat FSH EIA KIT (ALPCO Diagnostics, USA) were used for the analyses.

Testis tissue samples were kept in $10 \%$ formaldehyde. Tissues were embedded in paraffin blocks after a routine histological process. Sections of $5 \mu \mathrm{m}$ were taken from paraffin blocks and stained with hematoxyline-eosine. They were evaluated under a light microscope and then photographs were taken.

\section{Results}

\section{Macroscopical Evaluation}

At the end of macroscopical evaluation of both the first and second halves of the Experimental group (Groups 2, 4), outer anatomical appearance of rat testes were observed to be different from 


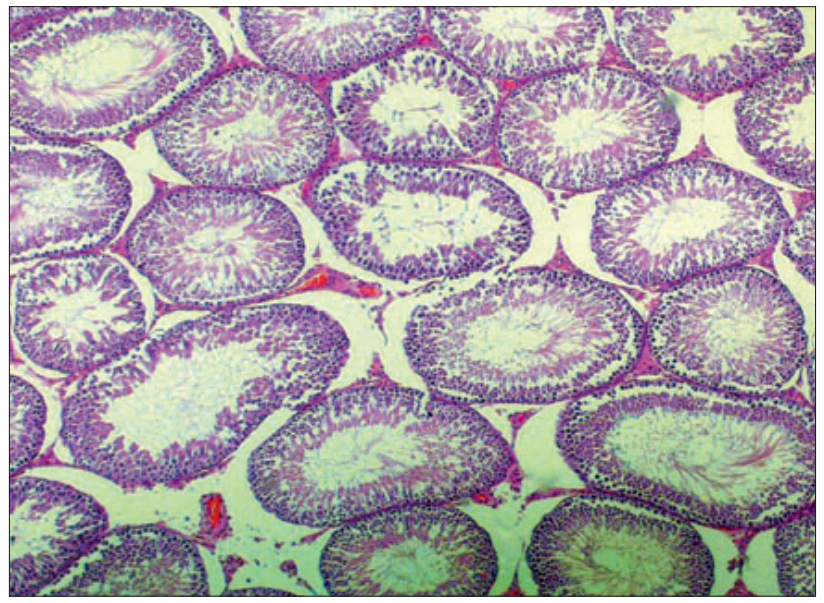

Fig. 1. The testicular tissue having seminifery tubules with normal histology (Control groups; Group 1 and 3) (Hematoxylin-Eosin x100).

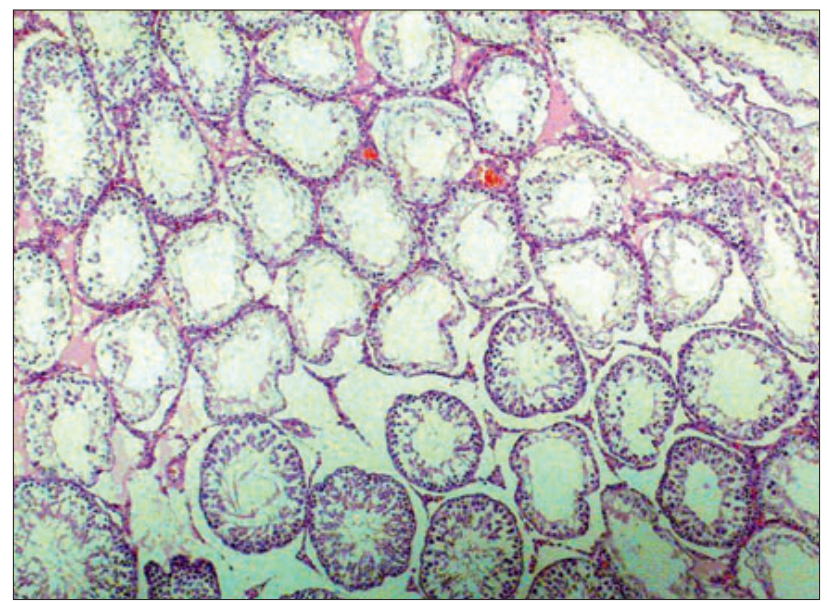

Fig. 2. Histological appearance of seminifery tubules with normal structure at the lower half and with spermatogenetic maturation at the upper half of the section. (Experimental group; Group 2) (Hematoxylin-Eosin $\mathbf{4 0}$ ).

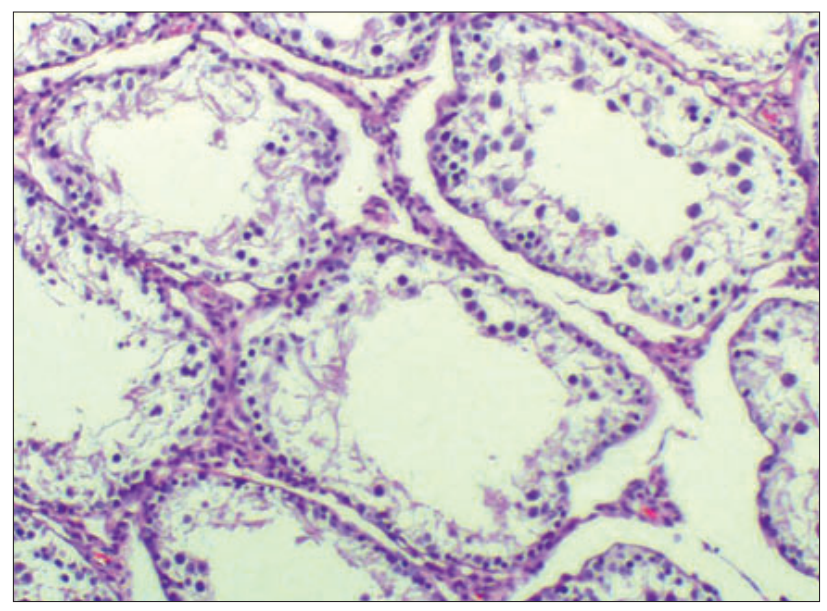

Fig. 3. Histological appearance of all seminifery tubules with arrested spermatogenetic maturation (Experimental group; Group 4) (Hematoxylin-Eosin x200).
Tab. 2. Differences between Group 1 and Group 2.

\begin{tabular}{lccc}
\hline Hormones & $\begin{array}{c}\text { Group 1 } \\
\text { Mean } \pm \text { Sd } \\
(\mathrm{ng} / \mathrm{ml})\end{array}$ & $\begin{array}{c}\text { Group 2 } \\
\text { Mean } \pm \text { Sd } \\
(\mathrm{ng} / \mathrm{ml})\end{array}$ & $\begin{array}{c}\text { Difference Between } \\
\text { Group 1 and } \\
\text { Group 2 }\end{array}$ \\
\hline FSH & $6.7 \pm 3.5$ & $13.6 \pm 3.5$ & $\mathrm{p}<0.05$ \\
LH & $1.1 \pm 0.5$ & $1.2 \pm 0.9$ & $\mathrm{p}>0.05$ \\
TSH & $1.02 \pm 0.9$ & $0.19 \pm 0.19$ & $\mathrm{p}<0.05$ \\
TESTOSTERON & $444.1 \pm 42.8$ & $453.7 \pm 39.3$ & $\mathrm{p}>0.05$ \\
ESTRADIOL & $1283.6 \pm 124.7$ & $1109.9 \pm 155.5$ & $\mathrm{p}<0.05$ \\
\hline
\end{tabular}

Tab. 3. Differences between Group 3 and Group 4.

\begin{tabular}{lccc}
\hline Hormones & $\begin{array}{c}\text { Group 3 } \\
\text { Mean } \pm \text { Sd } \\
(\mathrm{ng} / \mathrm{ml})\end{array}$ & $\begin{array}{c}\text { Group 4 } \\
\text { Mean } \pm \text { Sd } \\
(\mathrm{ng} / \mathrm{ml})\end{array}$ & $\begin{array}{c}\text { Difference Between } \\
\text { Group 3 and } \\
\text { Group 4 }\end{array}$ \\
\hline FSH & $3 \pm 0.4$ & $6.1 \pm 1.3$ & $\mathrm{p}<0.05$ \\
LH & $2 \pm 0.8$ & $0.91 \pm 0.39$ & $\mathrm{p}<0.05$ \\
TSH & $1.5 \pm 0.11$ & $1.8 \pm 0.2$ & $\mathrm{p}>0.05$ \\
TESTOSTERON & $475.8 \pm 10.7$ & $559 \pm 6.1$ & $\mathrm{p}<0.05$ \\
ESTRADIOL & $1286.1 \pm 12.3$ & $1212.3 \pm 25.1$ & $\mathrm{p}>0.05$ \\
\hline
\end{tabular}

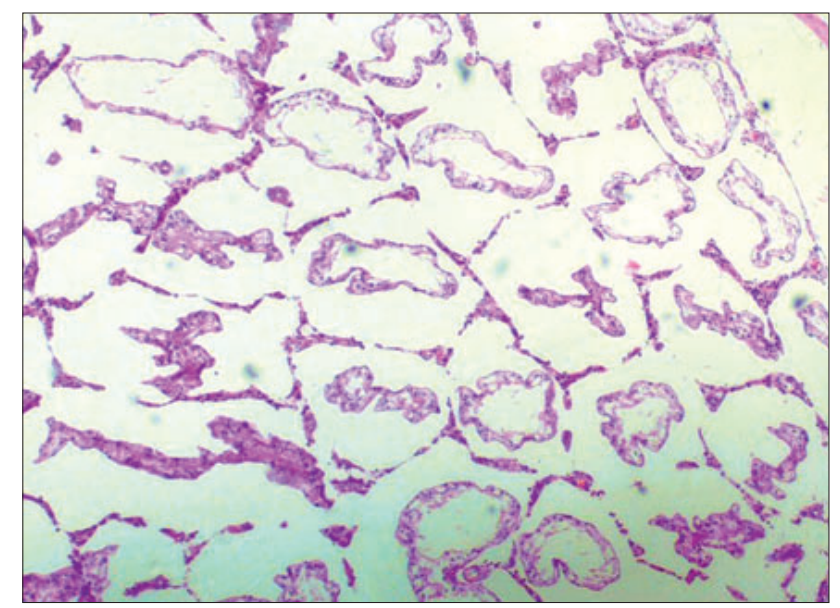

Fig. 4. Histological appearance of seminifery tubules with only sertoli cells (Experimental group; Group 4) (Hematoxylin-Eosin x40).

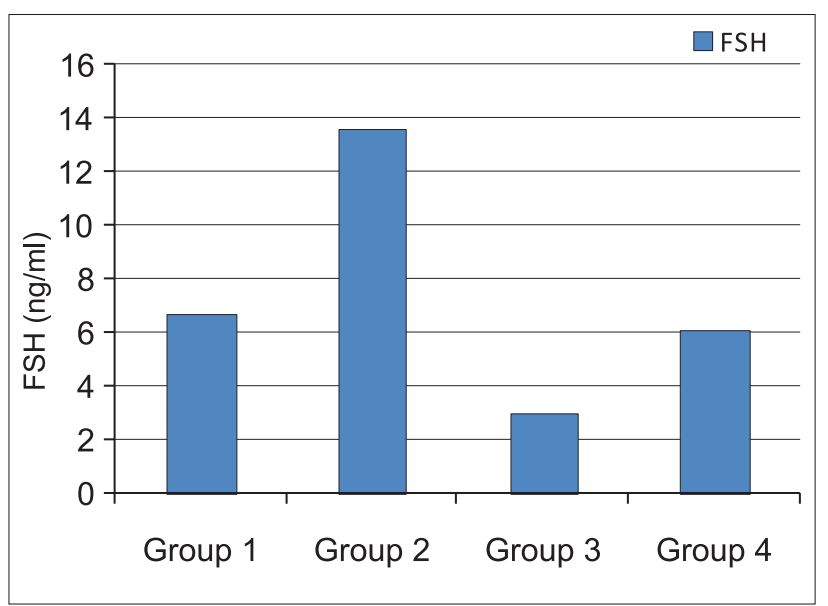

Fig. 5. The comparison of FSH level among the groups. 
normal structure and dimensions of the testes decreased (atrophied testes). However, the testes of rats were in normal appearance and size in the Control groups (Groups 1, 3).

\section{Histopathological Evaluation}

Testis tissues were detected to have normal structure microscopically in both Control groups (Groups 1, 3) (Fig. 1). Atrophy was detected in nearly half of testis tissues of all rats, the testes of which were transferred to abdominal cavity from the scrotal pouch in prepubertal period and fixed to the posterior surface of anterolateral abdominal wall for three months and were then removed surgically. Seminifery tubules with arrested spermatogenetic maturation were seen in the first half of the Experimental group (Group 2) (Fig. 2) (Tabs 2, 3).

We found out that in nearly all testis tissues atrophy developed and seminifery tubules with arrested spermatogenetic maturation and sertoli cells only were seen in rats, of which the testes were transferred to abdominal cavity from scrotal pouch and kept there for three months and then re-descended to scrotal pouch and kept in their regular site for another three months (Figs 3, 4)

We determined that experimental cryptorchidism, formed in pubertal rats by keeping the testicles in the abdominal cavity for three months, caused a partial damage in testicular tissues and the damage was found to persist in the testes that re-descended from the abdominal cavity to the scrotal pouch and were kept there for another three months (Figs 3, 4).

\section{Biochemical Evaluation}

The levels of FSH, LH, TSH, Testosteron and Estradiol in the sera of rats were found to be unchanged in the Control group, but a statistically significant increase was determined in FSH levels ( $<<0,01)$ in both Experimental groups (Groups 2, 4) compared to the Control group (Tabs 1-3) (Fig. 5).

This increase in FSH levels can be explained by increasing damage in the testicular tissues of the Experimental group of rats. The mechanism is that a destruction of sertoli cells in the seminifery tubules prevents the release of FSH inhibitory substances and this in turn will cause an increase in FSH. The increase of FSH in the blood appears as the most important indicator of damage in the testicular tissues.

\section{Discussion}

In this study, we aimed to establish the effects of experimental cryptorchidism formed in the prepubertal period at postpubertal and adult periods, and to find out what can be done on this subject, which is an important cause of infertility. The requirement for seriously controlling the location of testes in the scrotal pouch in newborn boys is a known reality. The testes should be descended by hormonal treatment or a surgical intervention as soon as they are noticed not to exist in the scrotal pouch. Any delay of descensus testis may cause not only infertility but also adverse effects such as development of malignant tumors of testes. We suggested that a simple control whether or not testes are in the scrotal pouch can prevent these adverse effects.
The mechanism of undescended testis is not clear at present and it is one of the most frequent pathologies requiring surgical intervention in pediatric urology. It is for this reason that the priority for hormonal or surgical treatment is also widely debated. Hormonal treatment is suggested in patients with bilateral or retractyl testes. Undescended testes must be descended surgically before 1 years of age because of the initiation of microscopical changes independent on receiving or not a hormonal treatment (14).

The incidence of cryptorchidism is related to the week and weight at delivery. Its incidence is almost $60-70 \%$ in boys with a delivery weight less than $1500 \mathrm{~g}$. While this ratio is $33 \%$ in prematures, it decreases to $3 \%$ in term males. Its incidence in one-yearold boys was found as $1.58 \%$ in a study in 1986 in England (15).

Undescended testes are reported to be in $30 \%$ in prematures in literature (16). In many other studies, similar rates were reported in newborn boys born earlier than the 37 th week of gestation and with low birth weight less than $2500 \mathrm{~g}$. Studies of large series were made to determine the natural history of descensus testis and the factors affecting postnatal descent $(17,18)$.

Transinguinal descent of testes takes place between the 24th and 28th week and is completed in the third trimester. Processus vaginalis becomes obliterated completely before the delivery and also gubernaculum is atrophied and transforms to a ligament. However, processus vaginalis has persisted to stay open in $90 \%$ of undescended testes. The testes descend into the scrotal pouch at the last $2 / 3$ period of gestation. The testes have already descended into the scrotal pouch at birth in more than $95 \%$ of term babies and in $79 \%$ of preterm babies. However, the descent of testes may be completed during the first year of life (19).

Isolated cryptorchidism is one of the most common congenital anomalies at birth. Cryptorchidism is encountered in 3\% of newborn boys. Unilateral cryptorchidism is more frequently (1.6-1.9 $\%$ ) compared to bilateral cryptorchidism. (20). The descent of testes into scrotal pouch is usually completed in the second trimester. However, a high cryptorchidism rate in prematures points out that the descent will be completed until delivery $(20,21)$.

These data shows that there is a significant relation between the descent of testes and prematurity, low birth weight, young according to gestational age and twin delivery (18). According to results of studies, 70-77\% of cryptorchidic testes descended spontaneously in the first three months after delivery.

The main cause of germ cell degeneration is a thermal environment. Testicular temperature is normally less than body temperature. Intraabdominal testes $\left(35-37^{\circ} \mathrm{C}\right)$ are warmer when compared to the normal scrotal testes $\left(33^{\circ} \mathrm{C}\right)(22)$. Timely diagnosis, accurate and appropriate treatment protects the patient from possible future problems such as infertility and malignancy. Testes migrate from the abdominal cavity $\left(37^{\circ} \mathrm{C}\right)$ into the scrotal pouch $\left(33^{\circ} \mathrm{C}\right)$, which has an environment with a lower temperature in many mammalians for healthy sperm production (20).

Recently, germ cell degeneration has been demonstrated to take place by means of programmed cell death (apoptosis) characterized with internucleozomal fragmentation as a response to thermal stress $(19,21-23)$. In this stage, thermal shock transcription fac- 
tor 1 is activated and induces apoptosis of primary spermatocytes, which results in infertility in male mice (24).

The timing for an operation is important for the surgical treatment of undescended testes. Structural degeneration in the early period of germ cells was observed in the previous studies. Various structural changes were established on an electron microscopy after 1 year and on a light microscopy after 3-4 years of age. Progressive macroscopical changes become marked in the primary school period. As the current approach, the operation is suggested to be performed between 12th and 18th month period even though the operation time is different in many centers $(25,26)$

The incidence of cryptorchidism decreases to $1 \%$ approximately at 1 year of age and this ratio continues at the same level until adult age (27).

Deterioration of germ cell maturation is a well-known result of criptorchydism. It is believed that the risk for subfertility is decreased when the testes are descended into scrotal pouch with early surgical intervention before histopathological changes were formed. But there are many data that orchiopexy does not lessen this risk. Previous reports focused on histopathological changes occurred in undescended testes at the 1st year of life. The reason for this was the probability of early surgical intervention to protect spermatogonial functions (28).

Ceylan et al. reported that (except ectopy) tfe irst-line treatment option in undescended testis should be hormonal, if this is unsuccessful, then the testes should be descended into scrotal pouch surgically. They also reported that the treatment of choice in postpubertal undescended testes is orchioectomy, orchiopexy may be performed following a testicular biopsy. This procedure may not support spontaneous fertility, however it may provide a source for IVF in the future in case of testicular dysfunction or orchioectomy in addition to its cosmetic benefit (8). Tellal et al. reported that semen parameters were disconcerted with the rate of $89 \%$ in unilateral group and $100 \%$ in bilateral group in males who had orchiopexy at a mean age of 13 . Surgical treatment decision should be made in the first year of life before these changes took place (29).

The risk of malignant degeneration in undescended testes is higher in criptorchid and contralateral normally localized testis than in the normal population. This risk may be lowered with orchiopexy (3). The incidence for development of malignancy in normally localized testes was reported as $1 / 100000$, however it was $1 / 2550$ in cases with undescended testes (30). Biopsies made recently from cryptorchid testes confirmed an inadequate transformation to type A spermatogonies, which forms the first step of postnatal spermatogenic development $(31,32)$. Gonocytes are present initially, but after then they undergo degeneration and cause insufficiency in total germ cell count. Although it is controversial, these degenerated cells may be a source of carcinoma in situ (33).

It was declared that being a father may be at risk in patients who had previous bilateral criptorchidism during childhood. Also it was shown that paternity wasn't correlated with orchiopexy age. In another study, paternity was positive in $87 \%$ of males with unilateral criptorchidism, while this rate was found as $33 \%$ in males with bilateral criptorchidism. In terms of development of infer- tility in cases with criptorchidism, other risk factors were shown to cause increased FSH and low sperm count. An additional risk factor in orchiopexy was also shown as the site of parenchymal testicular suture $(27,34,35)$.

An important factor in infertility is the unilateral or bilateral existence of criptorchidism. In studies conducted on male adults who were operated in childhood due to criptorchidism, the rate of true paternity in bilateral criptorchid males $(65.3 \%)$ was significantly lower than the unilateral criptorchid males $(89.7 \%)$ and control $(93.2 \%)$ group $(6,7)$.

Low inhibin B levels secreted from sertoli cells and regulating the secretion of FSH and high FSH levels are associated with high infertility risk (36).

We established atrophy and degeneration in vast majority of criptorchid testes of rats reached to puberty in our study. Also we found the atrophy and increase in cell degeneration of most of the testes of criptorchid rats in postpubertal period. We think that these changes may result in infertility. Additionally, we think that increased levels of estrogen and FSH are important in demonstrating the tissue injury in testes.

Higher inhibin B and lower FSH levels were determined in unilateral criptorchid males who had orchiopexy operation in 2nd year of life demonstrating that they benefited from an early surgical treatment (37). Higher estrogen and FSH levels explain a lower inhibin B level and testicular cell damage in our study. Results of our study are parallel to other authors' studies in terms of FSH and estrogen levels and testicular damage.

Another important risk related to criptorchidism is testicular malignancy. It is presumed that this risk has become 3-10 fold higher than normal recently $(38,39)$. Even though it has been thought that germ cell degeneration and testicular displasia could lead to malignancy, its mechanism is still debateful $(38,39)$. The effects of orchiopexy operation performed in the first year of life should be investigated both for infertility and malignancy. In our study, we think that risk of malignancy will be probably high in testicular cell degeneration in postpubertal and adult period of rats, which had experimentally formed criptorchidism in prepubertal period.

The timing for the descent of undescended testes into the scrotal pouch is very important and descending the testes into the scrotum as soon as possible before puberty is essential in lowering the risk of infertility.

In conclusion, we think that if cryptorchidism is not treated at the earliest stage in prepubertal and pubertal period, it may cause degeneration in testicular tissues. Also this degeneration may continue and increase at the postpubertal period. Thus, the testes should be descended into the scrotal pouch at the earliest possible time in cryptorchid males in prepubertal, pubertal, postpubertal or adult period in avoiding testicular malignancy.

\section{References}

1. McAninch JW. Disorder of the testis, scrotum and spermatic cord. In: Tanagho EA, Smith's General Urology. McGraw-Hill 15th ed. Int Ed 2000; 684-698. 
2. Cuz D AJ, Das K. Undescending testes. Ind J Pediat 2004; 71: 1111-1115.

3. Palmer JM. Undescended testicle. Endocrinol. Metab Clin North Am 1991; 20: 231-240.

4. Akand M. Testiküler inis, kriptorsidizm ve inguinal herni. Derleme, Infertilite; 135-139.

5. Elder JS. The undescended testis. Hormonal and surgical management. Surg Clin North Am 1998; 68: 983-105.

6. Lee PA. Fertility in cryptorchidism. Does treatment make a difference? Endocrinol Metab Clin North Am 1993; 22: 479-490.

7. Puri P, O'Donnell B. Semen analysis of patients who had orchidopexy at or after seven years of age. Lancet 1988; 2: 1051-1052

8. Ceylan K, Yilmaz Y, Yildiz A, Kus A, Gönülalan H. Kriptorşidizm. 164 olgunun; birlikte bulunan anomali, komplikasyon, tedavi modalitesi, hasta yaşı açısından irdelenmesi. TAD 2006; 4 (3): 24-26.

9. Mengel W, Hienz HA, Sippe WG et al. Studies on cryptorchidism: a comparison of histological findings in the germinative epithelium before and after the second year of life. J Pediatr Surg 1974; 9: 445-450.

10. Hadziselimovic F. Fertility and cryptorchidism. Am J Dis Child 1985; 139: 963-964.

\section{Raman JD, Schlegel PN. J Urol 2003; 170 (4 Pt 1): 1287-1290.}

12. Abe T, Aoyama K, Gotoh $T$ et al. Cranial attachment of the gubernaculum associated with undescended testes. J Pediatr Surg 1996; 31: 652-655.

13. Backhouse KM. The natural history of testicular descent and maldescent. Proc R Soc Med 1966; 59: 357-360.

14. Ozkısacik S, Yazici M, Oztan MO, Etensel B, Culhacı N, Gursoy MH. Does sepragel (hylan b) Have any Preventive Effect on Two-Stage Orchidopexy in the First Stage? ADÜ Tip Fakültesi Dergisi 2006; 7 (1): 11 - 14.

15. John Radcliffe Hospital Cryptorchidism Study Group: Boys with late descending testes: the source of patients with retractile testes undergoing orchidopexy. BMJ 1986; 293: 789.

16. Fentener van Vlissingen JM, Koch CA, Delpech B, Wensing CJ. Growth and differentiation of the gubernaculum testis during testicular descent in the pig: changes in the extracellular matrix, DNA content, and hyaluronidase, beta-glucuronidase, and beta- $\mathrm{N}$-acetylglucosaminidase activities. J Urol 1989; 142: 837-845.

17. Akre O, Lipworth $\mathbf{L}$, Cnattingius $S$ et al. Risk factor patterns for cryptorchidism and hypospadias (see comments). Epidemiology 1999; 10: 364-369.

18. Hadziselimovic F. Treatment of cryptorchidism with GnRH. Urol Clin North Am 1982; 9: 413-420.

19. Uyanik B. Saglikli Yenidoganlarda Ortalama Penis Boyu ve Ürogenital Anomali Sikligi, Uzmanlik tezi, Istanbul 2006.

20. Muller U, Donlon T, Schmid M et al. Deletion mapping of the testis determining locus with DNA probes in 46,XX males and in 46, XY and 6,X,dic(Y) females. Nucleic Acids Res 1986; 14: 6489-6505.

21. Frey HL, Rajfer J. Role of the gubernaculum and intraabdominal pressure in the process of testicular descent. J Urol 1984; 131: 574-579.

22. Tapanainen JS, Tilly JL, Vihko KK et al. Hormonal control of apoptotic cell death in the testis: gonadotropins and androgens as testicular cell survival factors. Mol Endocrinol 1993; 7: 643-650.

23. Mieusset R, Fouda PJ, Vaysse P et al. Increase in testicular temperature in case of cryptorchidism in boys. Fertil Steril 1993; 59: 1319-1321.
24. Billig H, Furuta I, Rivier C, Tapanainen $\mathbf{J}$ et al. Apoptosis in testis germ cells: developmental changes in gonadotropin dependence and localization to selective tubule stages. Endocrinology 1995; 136: 5-12.

25. Mieusset R, Bujan L. Testicular heating and its possible contributions to male infertility: a review. Int J Androl 1995; 18: 169-184.

26. NakaiA, Suzuki M, Tanabe M.Arrest of spermatogenesis inmice expressing an active heat shock transcription factor. 1. EMBO J 2000; 19: 1545-1554.

27. Yilmaz Y, Özen IO. Inmemis Testis Kliniginde Güncel Yaklasimlar. STED; cilt 13, sayi 6. 2004; 211-214.

28. Basaklar AC. Inguinoskrotal bölge hastaliklari. Yenidoganın cerrahi hastaliklari. Palme Yayincilik Ankara 1994; 376-399.

29. Andersson S, Geissler WM, Wu L et al. Molecular genetics and pathophysiology of 17 beta-hydroxysteroid dehydrogenase 3 deficiency. J Clin Endocrinol Metab 1996; 81: 130-136.

30. Attah AA, Hutson JM. The role of intra-abdominal pressure in cryptorchidism. J Urol 1993; 150: 994-996.

31. Tellaloglu S, Kadioglu A, Kilicaslan I, Alipour M, Kadioglu T, Ziylan O. Cryptorchidism. Is orchidopexy always preventive treatment for infertility. Acta Chir Hung 1994; 34: 195-201.

32. Farrer JH, Walker AH, Rajfer J. Management of the postpubertal criptorchid testis: a statistical review. J Urol 1985; 134; 1071-7106.

33. Huff DS, Hadziselimovic F, Snyder HM et al. Histologic maldevelopment of unilaterally cryptorchid testes and their descended partners. Eur J Pediatr 1993; 152 (Suppl 2): S11-14.

34. Güllüoglu I. Orkiopeksi operasyonunda basşariyiı etkileyen faktörler. Uzmanlik tezi, T.C. Sağlık Bakanligi Sisli Etfal Egitim ve Arastirma Hastanesi, Istanbul 2004.

35. Huff DS, Hadziselimovic F, Snyder HM et al. Postnatal testicular maldevelopment in unilateral cryptorchidism. J Urol 1989; 142: 546-548.

36. Taskinen S, Hovatta 0, Wikstrom S. Early treatment of cryptorchidism, semen quality and testicular endocrinology. J Urol 1996; 156: 82-84.

37. Skakkebaek NE, Berthelsen JG, Giwercman A et al. Carcinoma-insitu of the testis: possible origin from gonocytes and precursor of alt types of germ cell tumours except spermatocytoma. Int J Androl 1987; 10: 19-28.

38. Miller KD, Coughlin MT, Lee PA. Fertility after unilateral cryptorchidism. Paternity, time to conception, pretreatment testicular location and size, hormone and sperm parameters. Horm Res 2001; 55: 249-253.

39. Attah AA, Hutson JM. The role of intra-abdominal pressure in cryptorchidism. J Urol 1993; 150: 994-996.

40. Coughlin MT, Bellinger MF, Lee PA. Age at unilateral orchiopexy. Effect on hormone levels and sperm count in adulthood. J Urol.1999; 162: 986-988.

41. Lee PA, Coughlin MT, Bellinger MF. Inhibin B. Comparison with indexes of fertility among formerly cryptorchid and control men. J Clin Endocrinol Metab 2001; 86: 2576-2584.

42. Carmona Campos E, Regueiro Lopez JC, Prieto Castro R et al. Cryptorchidism and testicular cancer. Actas Urol Esp 2000; 24: 49-51.

43. United Kingdom Testicular Cancer Study Group. Aetiotogy of testicular cancer: association with congenital abnormalities, age at puberty, infertility, and exercise. BMJ 1994; 308: 1393-1399.

44. Haughey BP, Graham $\mathbf{S}$, Brasure $\mathbf{J}$ et al. The epidemiology of testicular cancer in upstate New York. Am J Epidemiol 1989; 130: 25-36.

Received June 6, 2012. Accepted August 18, 2012. 